\title{
A COMPARATIVE VIEW REGARDING THE TERRITORIAL-ADMINISTRATIVE REFORMS AND LOCAL GOVERNANCE IN POLAND AND CZECH REPUBLIC
}

\author{
Aurora Ndreu ${ }^{1}$
}

\begin{abstract}
The purpose of this article is to file the administrative-territorial reforms, conducted by Poland and Czech Republic, in a comparative point of view. This study has been done conducted on unitary former communist countries such as Poland, Czech Republic and Croatia, which resemble Albania as a result of their past. Looking at the historical evolution of reforms in these countries with different local governance systems, and analysis of the latest developments will give us a deeper knowledge about the topic.

This comparison would address reforms of the political bodies of local government (such as those relating to political accountability and decision-making in local government), with regard to administrative structures, because only by looking at both sides of the currency of the local government can we get a complete picture of the changes and improvements to be made.

Comparison aims at providing knowledge about the terminology and concepts used in the comparison of countries and characteristics of each country in connection with the territorial administrative reforms carried out, followed by a reformation of the local government.
\end{abstract}

JEL Classification Numbers: K300 DOI: http://dx.doi.org/10.12955/cbup.v4.816

UDC Classification: 342 ’35

Keyword: territorial-administrative reform, local governance, Poland, Czech Republic, regionalization, recentralization.

\section{Introduction}

Both the countries compared in this article were previously into a communist system, same as Albania. The implementation of the territorial-administrative reform in these countries would help as a guidance for the good implementation of the same reform in Albania.

\section{Local Governance in Poland - The administrative-territorial reforms}

Poland is historically a unitary state. Cultural and economic differences have always existed between the southeast and northwest regions of Poland. Administrative-territorial reform in Poland between the years 1950-1973, somewhat reflected the divion of the Soviet communist system with three levels, composed of 17 provinces, 300 districts and 8,000 municipalities. Infrastructure, economic development, cultural relations and historical relations were best represented by districts called powiat, so this form of organization has been more stable over the years. The two-level organization included provinces, which, after the reform became 49 from 17 and municipalities were reduced in number by 2500 . The reason to undertake such a reform was to reduce the power of the party-state in these centers and destroy the emotional bond that existed between people of the district unit. Although, at the time people were told that the reform was to decentralize power, it centralized it even more.

During the communist era, several organizations called proto-self-governing organizations were created that dealt with the elite group and made the decentralization process easier after the fall of the communist system in this country. The reform and law of 1990 introduced the first democratic election at the local level, it also changed the definition of ownership passing the right of ownership to municipalities, and introduced the concept of local budgets and their management by the local authorities (J. Yoder, 2003, p. 8). On the basis of this reform, local government took a different meaning, where the local representatives took on new responsibilities. Selected organs were created directly by the people such as those of the local councils. Organization in voivodships, to compare by organization and function in Albania, would have been called prefectures, and still acted at a local government level. However, these organizations had limited liability, involving merely the execution of the decisions made by the central government. The most delicate problem in the post-communist

\footnotetext{
${ }^{1}$ Aurora Ndreu, European University of Tirana, Tirana, Albania, aurorandreu84@gmail.com
} 
period was not having sufficiently experienced personnel in small local units which led to financial problems in these units.

In June 1990, another subdivision called rejon, was implemented. This was a quasi-subdivision of the voivodship administration, but didn't have its own functions, which was done merely for technical and organizational reasons. During subsequent years, several efforts were made to undertake reform but these effort were constantly hampered due to the absence of political will. Consequently, administrative reform was interrupted until 1997, when the key political supporters came back into power, who in addition to local government reform, sought to reform education, healthcare, and justice. This lead to a decisive separation from the old communist system and its inherent ways of governance. The new reform aimed at decentralization of many public functions, such as public services and public finances, to local bodies. Eventally, it was necessary for the central government to deal with policies that have an effect on macroeconomic policies outside the country, or those of public safety. The administration of public services was left in the hands of the local government functions. On January 1, 1999, the administrative reform came into effect, after the elections the new local councils took place (Yoder J. 2003; 11). The reform in our country was implemented after the local elections of June 2015, the organization was done under the new division. After the abovementioned elections in Poland, the basic unit of local government, gminy, had full rights over the management of kindergartens, elementary schools, libraries, cultural centers, development and management of roads, parks, etc. These units were also responsible for the control of land management, urbanization, sanitation, drinking water, supply or electricity, public transport and more. Meanwhile, responsibility to protect the public order and security was to be shared with other levels of government organs. Powiaty as an organization, was responsible for matters not covered by the unit base, such as, secondary education and public health services, which is basically the management of services that extend beyond the boundaries of gminy. Local councils were called sejmiki, who were elected in free and general elections, these then elected the executive bodies that performed executive functions in the unit where they lay. They were responsible for the approval of local development policies, both economic and social. These were independent bodies and have their own budgets. Their responsibilities were supra-local in character, such as higher education, cultural heritage, etc. This is where the local system in Albania is different because at any level of government in Albania, such as the base or the second level, that are region called qark, which according to the new laws (Local selfgovernment Law (2015), can't exercise responsibilities pertaining to education high.

Another characteristic of Poland is the existence of a parliamentary system of local government organs. This means that local councils are elected through general elections and in turn choose the executive organs of local government, which is not the case in current Croatian or Albanian systems. These executive boards that are chosen by local councils, are run by the marshals. Wojewody were officials appointed by the central government that represented the central government at regionallocal levels. These types of officials resembles the prefects in the Albanian system, who oversees the decisions made by local councils and check their compliance with the law. Their existence shows a dualistic structure of the administration. Wojewodztwa, the wojewody body, could build several bilateral and multilateral relations with foreign partners. Implementation of this reform in Poland and the regionalization of the country will lead to better us of the European Union funds, so in the future, these regions can be a key factor in the integration process of Albania. The reason for undertaking any administrative reform should be to increase the accountability of ordinary citizens by the public institutions, by monitoring and ensuring that funds are managed in the most efficient manner possible. Through the decentralization of key functions, it becomes possible for the central government to make decisions regarding major strategic issues and policies, while the local government will deal with daily life functions of citizens.

As a fact, the administrative reform in Albania should have provide a modern state, able to effectively use human and financial resources, similar a democratic country where public and private values belong to European society. By implementing the reform, creation of a state that will function in accordance with the procedures and laws is intended, represented by representatives elected directly by the people. A state where the local and regional community decides to create its own identity and manage its own local affairs, where the principle of subsidiarity is respected by all levels of government. The principle that many functions dealing with citizens must carried out by bodies that 
are closer to the citizens is one of the fundamental principles of the European Union. Other principles of reform must also be transparency, effectiveness, accountability and flexibility in carrying out functions.

Poland undertook its administrative reform and made a significant and meaningful move towards decentralization and regionalization. The main reason for this reform by the Polish government was the quality of democratic governance, integration into the European Union and generally, the global economic policy. Usually, reform was crucified and described by the opposition as a waste of public funds, stating that reorganization was worthless. Finally, on the basis of the legal analysis, Poland remains a unitary state, like Albania and cannot reach comprehensive regionalism or federalism. This is why the two countries are historically and traditionally unitary.

\section{Aspects of the reform and local governance in the Czech Republic}

In antagonism with Poland, the Czech Republic comes from a long tradition of local public administration in land or regional level. This is because it has taken the administrative traditions of its neighboring countries, such as Germany, Switzerland, and Austria, who have a federalized system of government. The core of Czech state since the XI century is made historically by the two main regions, Bohemia and Moravia. Since the region of Moravia and Silesia was under the rule of the Hapsburgs, they enjoyed local and regional autonomy. On the other hand, the Slovak region was under Hungarian Crown, which did not enjoy the benefits of local self-government (Yoder J. 2003, p. 13-15). When Czechoslovakia, which was created as a multi-national state, was divided into several regions after World War II, it was reconstructed as a unitary state, as a single federation, which also formally ended de facto. Until 1990, Czech Republic and Slovakia had a local government system consisting of three levels of government: municipal, district and region. During the communist system, the philosophy was to destroy the historic provinces of Bohemia, Moravia and Slovakia, in order to establish the link between their economic development. First, communist authorities created 19 large regions called kraje, which were later reduced to 10 in 1960, and two urban centers. The purpose of these regions was to execute the orders of the central government. Consequently, each region was controlled by a centralized national council. These regions were divided into 76 districts called okres and over 7,500 municipalities called obec (Yoder J. 2003; 16). Czechoslovakia federalism as a result of the Prague Spring of 1968, brought the centralized Soviet system. This kind of federalism meant harsh centralization of functions. After 1990, the new system did not have 3 levels, as regions did not exist anymore, because they were viewed by the system as arbitrary administrative unit that had no historical roots. National councils were also eliminated, being remnants of the old system. Municipalities and communes were already recognized as the basic unit of local government. These local governments have the right to initiate local decisions and legislation, while assemblies with elected councilors had the legislative and executive functions. Among the responsibilities of government organs, were granting building permits for the area under administration, as in the case of Albania, and the administration of the property of the municipality, obtaining grants, preparation of local budgets, the establishment of other entities, fulfillment obligations with respect to education, and health or other areas that were not responsibility of other levels. Innovation in this analysis is the fact that these local bodies also had responsibility regarding the management of local public order and the municipal police. At this point it is unclear whether this is a matter for a municipal police in the case of Albania with limited rights (Local self-government Law (2015), or a policeman who kept assuring public order such as the police state, but that depends on local government organs. At the district level, directly elected bodies were not provided, but they functioned as an extension or continuation of the central authorities in order to fulfill tasks related to state administration. We also find here a similarity with the prefect organ in our system, as in some cases, these agencies have the right to cancel decisions of municipal bodies (Law on Prefect, 2002). A critical attitude towards this kind of organization, is the fact that there is no link between the municipal level, the one governing the district, and central level executive authorities. There is also criticism regarding the solution of regional problems, as it is not stipulated in the law, who must be addressed for solutions. In the present case, the administrative reform was the most sensitive and problematic compared to Poland. This is because the status the lander would have in the future, historically existed in the IX century, Moravia and Silesia. This problem arises from the fact that, giving a different status to these regions, will lead to a dualistic administration and this was, in fact, 
the cause of the division of Czechoslovakia in 1992. The special commission that was set up in 1990 to implement the administrative reform, analyzed examples of Germany, Austria and Italy, where the final proposal selected: an administrative division based on the former division of Lands; a variant with the provinces, which will lead to the creation of 15-20 provinces or extended districts which was still highly centralized; a combination of the first two, the provinces based on historical Lands division, creating the subsidiary organs of self-government bodies but also centers at the provincial level; review of the federal system, making each of the regions, the Czech, Slovak, Moravia, Silesia to have separate state organization and constitution. In 1992, the reform issue was overshadowed as a result of the major problems that the country was facing, i.e. the division into two states. Only in 1993, after a new state was created, the Czech authorities were forced to take the reform back to treatment, after the constitution forced the formation of local government units, self-governing with councils elected every 4 years. In this year, two committees were created that would present proposals, one proposal presented consisted of the 12-14 division Lands with self-governing and representative bodies of local and central government. The other commission proposed division into 8 other self-governing units. Debates on the reform and which variant would be resolved lasted until 1997, when Constitutional Act on the establishment of Regions was adopted, by which 14 high selfgoverning units or kraje were created. This law did not regulate issues of regional councils or their functions, and thus there were many debates on the issue in question from the central as well as local authorities. During the implementation of reform, districts and municipalities continued to exist, finally districts ceased to exist in December 2002. The development of such a reform brought a greater economic development, enabling these already extended units, to participate and decide on the different policies in international organizations and cooperation with other units of other states. One reason for undertaking reform in the Czech Republic was constant demand from the European Union regarding decentralization. In a union where the movement is toward unification of many policies, it is important to put an emphasis on decentralization of the regions as they emerge as separate entities in regional policies. According to the Regional Law that was passed in 2000, regional assemblies elect and dismiss the regional governor and the regional council. These assemblies can approve regional budget and submit draft proposals to the Chamber of Deputies about different issues. Significant changes regarding the competence of the regions came into law in 2000, when management of secondary education were given several schools of art that had previously been subordinated to the central government or the relevant ministry of education. Management of roads, galleries, libraries and museums was added to this. The Czech case about reform differs from that of Poland, because the latter was an important division of the communist system and undertaking a new organization. So in Poland, the reform was linked to division of the country from the communist period. In the case of Czech Republic, pressure from outside or the European Union and the integration process influenced the adoption of reform fast. The greatest fear of Czechs about regionalization lay in the fact that in a regional economic development, the regions of Moravia and Silesia can be empowered and in the future may require a full federalization or worst, division, similar to 1992, when Czech divided from Slovakia.

\section{Conclusion}

The transition from a communist system to a democratic system after 90s, made decentralization or regionalization difficult for countries. This is because the immediate need was to put in place a democratic governing system with such laws and bodies as well as its full implementation. It was only after such a venture that these countries proceeded with reforms such as regionalization and decentralization. In each case the reform was influenced by communist mentality of those who undertook reform, and the fact that there was no establishment of a local pre-communist autonomy made the process difficult. Given that the reform would include many types of issues or modification, change in borders and names of the regions, it raised a concern regarding the loss national identity or national union of regions. Another concern was the creation of national and regional political leaders, where they might overwrite each other, changing perceptions about expectations of policy implementation by regional and national leaders. Reform opponents feared that decentralization will lead to loss of their authority. Similar to the case of British conservatism, the Czech Republic there were concerns that regionalization, decentralization and Europeanisation will not bring any good to the country. Because according to them it will lead to loss of national sovereignty and would weaken 
the power of the central government. The issue of decentralization and regionalization was deemed to have a negative impact as the strengthening of the autonomy of minorities due to any regionalization made pursuant to the protection of their rights (as it was under the administrative reform recently in Albania) was thought to lead to loss of national identity among the population or even possible secession from the state it belong to. We are yet to see if pursuant to the protection of minority rights will be created by municipalities created in Albania.

\section{References}

The Parliament of Albania, Law no 8927/2002 (2002). "Law for Prefect"(2002). Retrieved March 1, 2016 from http://www.planifikimi.gov.al/sites/default/files/Ligj_8927_25.07.2002_Per\%20prefektin.pdf

The Parliament of Albania, Law no 139/2015 (2015). "Local self-government law" (2015) Retrieved February20,2016fromhttp://www.ceshtjetvendore.gov.al/files/userfiles/LIGJI139_2015_PER_VETEQEVERISJEN_VEND ORE1.pdf

Yoder, J. A. (2003). "Decentralisation and regionalization after communism: Administrative and territorial reform in Poland and Czech Republic", Europe-Asia studies, vol 55, no 2, pp 263-286. 